\author{
V. A. KLIMENKO', Y. A. YANOVSKAYA ${ }^{1}, Y$. V. PASICHNIK², \\ O. Y. MARCHENKO (Kharkiv, Ukraine)
}

\title{
CLINICAL CASE OF TUBERCULOSIS IN INFANT WITH BRONCHIAL OBSTRUCTIVE SYNDROME
}

\author{
${ }^{1}$ Kharkiv National Medical University; ${ }^{2}$ Regional Children's Hospital No.1; \\ ${ }^{3}$ Kharkiv Academy of Postgraduate Education <ekaterinapediator@gmail.com>
}

\begin{abstract}
The objective of this article is to improve the etiology verification of the obstruction in young children by informing the physicians about the rare causes of obstructive syndrome which are difficult to diagnose, in particular about tuberculosis. Analyzed the clinical and medical history girls 6 months, presented data on the treatment and examination of the patient. The survey revealed that the main pathogenetic mechanism of bronchial obstruction of airway compression was increased bronchopulmonary lymph nodes on the background of specific tubercular process in lungs.
\end{abstract}

Key words: infants, pneumonia, tuberculosis, bronchial obstructive syndrome.

Bronchial obstructive syndrome or the syndrome of bronchial obstruction is a symptom complex associated with the obstruction of bronchial patency of a functional or organic origin. Nevertheless, the aforementioned term cannot be used as separate diagnosis and requires the determination of the nosological entity. There are four main groups of causes of bronchial obstruction: infectious, allergic, obstructive, and hemodynamic $[4,5]$. These pathogenic mechanisms account for the following diseases concurrent with bronchial obstructive syndrome [4-6]:

1. Respiratory diseases: 1.1) infectious and inflammatory diseases (bronchitis, bronchiolitis, pneumonia); 1.2) asthma; 1.3) aspiration of foreign bodies; 1.4) bronchopulmonary dysplasia; 1.5) bronchopulmonary system deficiencies; 1.6) bronchiolitis obliterans; 1.7) tuberculosis.

2. Gastrointestinal diseases (esophageal achalasia and achalasia, gastroesophageal reflux, tracheoesophageal fistula, diaphragmatic hernia).

3. Hereditary diseases (cystic fibrosis, alpha-1-antitrypsin deficiency, mucopolysaccharidosis, rickets-like diseases).

4. Parasitic infections (toxocariasis etc.).

5. Cardiovascular diseases.

6. Central and peripheral nervous diseases (birth injury, myopathy etc.).

7. Congenital and acquired immunodeficiencies.

8. Exposure to a variety of physical and chemical environmental factors.

9. Other reasons (endocrine diseases, systemic vasculitis, thymomegalia etc.).

Many of the foregoing diseases are well-known to practical healthcare physicians (e. g., asthma, gastroesophageal reflux and others.), while some of them remain difficult for differential diagnosis, first of all due to the lack of physicians' medical knowledge in this sphere. This article is aimed at raising the physicians' level of knowledge regarding the clinical peculiarities of tuberculosis in young children [1-3, 7-10].

The objective of this article is to improve the etiology verification of the obstruction in young children by informing the physicians about the rare causes of obstructive syndrome which are difficult to diagnose, in particular about tuberculosis.

Research results and discussion. A girl named Sh., 6 months of age, was hospitalized to the Pulmonary Unit of MHCI «Regional Children's Clinical Hospital No. 1», Kharkiv city, on 18 May 2015, with complaints on shortness of breath, cough, noisy 
breathing, which appeared from the first month of the child's life and intensified in the morning hours, weakness, loss of appetite .

It is known from the medical history that the child was transferred from Artyomovsk Central District Hospital (Artyomovsk CDH). She was admitted to the said hospital with the abovementioned complaints on 05 May 2015 on the background of significant catarrhal symptoms of upper respiratory airways with a one-time increase in temperature up to $37.8{ }^{\circ} \mathrm{C}$. On admission to the $\mathrm{CDH}$, the child's condition was assessed as moderate due to the obstructive syndrome. The skin integument cover was pale. The faucial mucosa was significantly hyperemic. The thorax was emphysematously inflated. By percussion there is a box sound, while auscultatory in the lungs one may observe non-productive wheezing from both sides. Physical data regarding other organs and systems are without abnormalities.

Inter alia, the complete blood count (from Artemovsk $\mathrm{CDH}$ ) is as follows:

05 May 2015: Hb - $92 \mathrm{~g} / \mathrm{l}, \mathrm{RBC}-3.9 \cdot 10^{12} / \mathrm{l}$ WBC $-17.1 \cdot 10^{9} / \mathrm{l}$, ESR $-35 \mathrm{~mm} / \mathrm{h}$, eosinophils $-1 \%$, banded neutrophils $-3 \%$, segmented neutrophils $-51 \%$, lymphocytes $-34 \%$, monocytes - $11 \%$ (significant leukocytosis, accelerated ESR, anemia).

08 May 2015: Hb - $102 \mathrm{~g} / \mathrm{l}, \mathrm{RBC}-4.08 \cdot 10^{12} / \mathrm{l}$, WBC $-12.2 \cdot 10^{9} / \mathrm{l}$, ESR $38 \mathrm{~mm} / \mathrm{h}$, eosinophils $-1 \%$, banded neutrophils $-12 \%$, segmented neutrophils $-50 \%$, lymphocytes $-24 \%$, monocytes - 11\% (leukocytosis, accelerated ESR).

12 May 2015: $\mathrm{Hb}-107 \mathrm{~g} / \mathrm{l}, \mathrm{RBC}-4.31 \cdot 10^{12} / \mathrm{l}$, WBC $-10,3 \cdot 10^{9} / 1$, ESR $24 \mathrm{~mm} / \mathrm{h}$, eosinophils $-1 \%$, banded neutrophils $-1 \%$, segmented neutrophils $-45 \%$, lymphocytes - $41 \%$, monocytes - $12 \%$ (moderate, accelerated ESR).

The chest X-Ray (05 May 2015) showed no infiltrative changes in the lungs and the obtained data suggested that there was acute bronchitis.

The patient received the following medical treatment: amoxicillin with clavulanic acid, dexamethasone, inhalations with salbutamol and fluticasone propionate.

The child's condition deteriorated over time and as a result the child was transferred to Kharkiv RCCH No. 1.

As known from the medical history, the child was born from the third pregnancy, which proceeded with toxicosis in the I and II trimesters and while the mother had bronchitis and smoked (the first child died, the second child is four years old and in good health). This was the third childbirth in the term of 37-38 weeks. Weight at birth -3250 g, caesarean section. The baby is bottle-fed from birth and is not vaccinated. The maternal grandmother suffers from diabetes. Place of residence: Donetsk region, Avdiivka city.

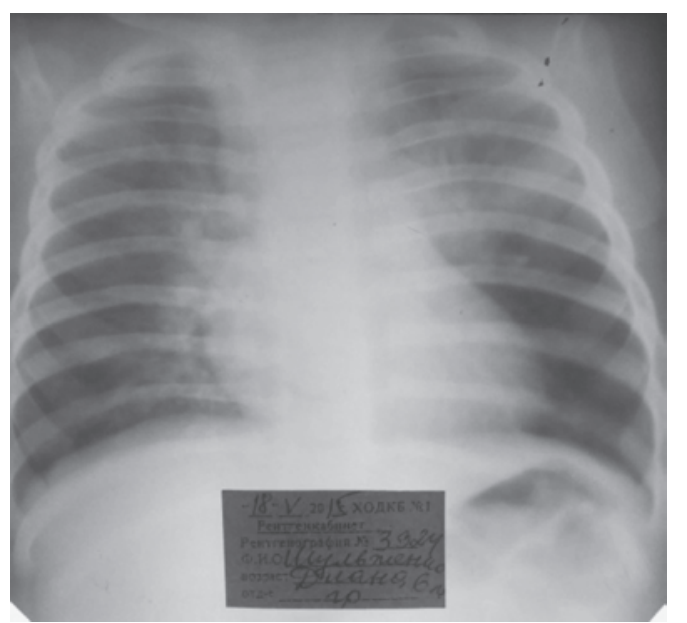

Fig. 1. X-Ray No. 1 (18 May 2015): in the upper field of left lung (view $\mathrm{S}_{\mathrm{II}}-\mathrm{S}_{\mathrm{III}}$ ) an area of airspace disease of infiltrative nature was detected. Medical conclusion: left-sided polysegmental $\left(\mathrm{S}_{\mathrm{II}}-\mathrm{S}_{\mathrm{III}}\right)$ pneumonia
On admission to the RCCB No. 1, the child's condition was of moderate severity due to respiratory disorders. In particular, the doctors noted strident breath, rare nonproductive cough as well as clean pale skin. The thorax was emphysematously inflated, and dry wheezes with medium bubbling moist rales were auscultatory heard from both sides against the background of weakened breath as well as the unheard bubbling rales in the upper left fields.

The child was subjected to chest X-Ray No. 1 (18 May 2015): in the upper field of left lung (view $\mathrm{S}_{\mathrm{II}}-\mathrm{S}_{\mathrm{III}}$ ) an area of airspace disease of infiltrative nature was detected. Medical conclusion: left-sided polysegmental $\left(\mathrm{S}_{\mathrm{II}}-\mathrm{S}_{\mathrm{III}}\right)$ pneumonia (fig. 1).

The preliminary diagnosis on admission was as follows: hospital left-sided polysegmental $\left(\mathrm{S}_{\mathrm{II}}-\mathrm{S}_{\mathrm{III}}\right)$ pneumonia complicated with bronchial obstructive syndrome, acute course. Congenital stridor. 
From examination in RCCH No. 1:

Complete blood count - hypochromic anemia ( $\mathrm{Hb}-86 \mathrm{~g} / \mathrm{l})$.

Urinalysis, coprogram - no abnormalities.

Clinical sputum analysis: white blood cells - up to $1 / 4$ per HPF, red blood cells unchanged in some places, bronchial epithelium elements - 25-35 per HPF, alveolar cells (macrophages) - 0-4 per HPF, eosinophils - 0-4 per HPF, tuberculosis mycobacteria- not found.

Bacteriological inoculation of mucus and oropharynx: Staphylococcus (S.) epidermidis $10^{3}$, Pseudomonas (P.) alcaligenes $10^{3}$, Escherichia (E.) cloacae $10^{3}$, Streptococcus (Str.) pneumoniae $10^{6}$, Str. spp. $10^{5}$.

Sputum bacteriological inoculation: Klebsiella (K.) pneumoniae $10^{3}$, Acinetobacter (Ac.) lewoffii $10^{3}$, Str. spp $10^{3}$.

ECG: sinus arrhythmia.

Echocardiography: average pressure in pulmonary artery - $26.3 \mathrm{~mm} \mathrm{Hg}$. Abnormal chorda of the middle third of the left ventricle.

Ultrasonography: expansion of cerebrospinal fluid spaces.

The child was examined by the following specialists:

ENT physician: congenital stridor cannot be ruled out. No acute pathology of ENT organs was detected as of the moment of the examination.

Neurologist: syndrome of liquor-dynamic disorders due to hypoxic-ischemic CNS injury in the perinatal period.

Cardiologist: Secondary cardiomyopathy, 1 stage of secondary pulmonary hypertension.

Consultation of children's phthisiologist (25 May 2015): considering the absence of DCG vaccination and the disease duration, one cannot rule out the specific etiology of the disease. Therefore, it is recommended to perform the Mantoux test with 2TE and thoracic CT scan.

Thoracic CT-scan (28 May 2015): an area of lung tissue infiltration in upper fields of left lung is detected in the spiral mode with the reconstruction interval of $3 \mathrm{~mm}$ in the course of multidimensional reconstruction (the projection of segments I-III). Peribronchial lymph nodes of left chest part are enlarged to 6-12 mm.

Medical conclusion: left-sided polysegmental pneumonia (projection of segments I-III).

X-ray No. 2 (02 June 2015). Medical conclusion: positive dynamics in the form of partial resolution of pneumonic infiltration in the left lung.

However, taking into consideration the massive nonspecific antibacterial (cefepime, vancomycin, meronem), anti-inflammatory (dexamethasone, fluticasone propionate) and broncholytic therapy (aminophylline, salbutamol, ipratropium bromide + fenoterol), the child's condition as of 02 June 2015 objectively remained severe due to persisting respiratory disorders. One should also note strident breathing and dyspnea with a dominantly expiratory component when the child is anxious. The child was hyposthenic, the cough was rare and nonproductive, the skin was clean and pale, the thorax was emphysematously inflated, dry wheezes with medium bubbling moist rales were auscultatory heard predominantly from the left upper fields.

The repeated consultation of phthisiologist was conducted on 02 June 2015. Medical conclusion: the response to the Mantoux test with 2 TU from 26 May $2015-6 \mathrm{~mm}$ suggests the mycobacterium tuberculosis infection in young the child not vaccinated with BCG. Against the background of broad-spectrum antibiotics treatment a positive radiologic dynamics was achieved in the form of partial resolution the of pneumonic infiltration in the left lung. Taking into account the inconsistency of Chest X-ray results with the absence of the clinical effect, it is required to repeat thoracic CT-scan.

In control thoracic CT-scan on 10 June 2015, in segments $\mathrm{S}_{\mathrm{I}}-\mathrm{S}_{\mathrm{III}}$ we detected the lung tissue infiltration of high intensity with the atelectatic component, conjugated with enlarged lymph nodes of $10.5 \mathrm{~mm}$ in diameter (fig. 2, 3). There were no focal and infiltrative opacity in the right lung. The lung pattern was enhanced due to the vascular component. The trachea and large bronchi were non-obstructive and no free fluid was detected in pleural capacity. Enlarged mediastinal lymph nodes are found on the left side: paraaortal - up to $6 \mathrm{~mm}$, paratracheal - up to $8 \mathrm{~mm}$, bifurcational - up to $10 \mathrm{~mm}$ (see fig. 2). 


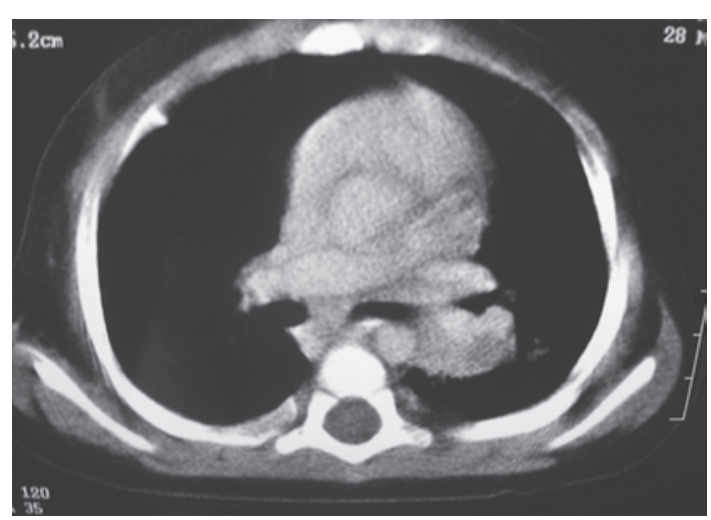

Fig. 2. CT-scan on 10 June 2015. Enlarged mediastinal lymph nodes are found on the left side

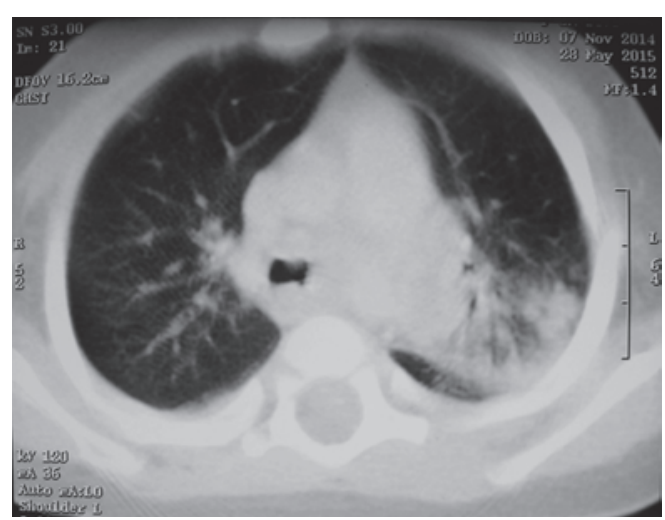

Fig. 3. CT-scan on 10 June 2015. In segments $\mathrm{S}_{\mathrm{I}}-\mathrm{S}_{\mathrm{III}}$ there were detected the lung tissue infiltration of high intensity with the atelectatic component, conjugated with enlarged lymph nodes of $10.5 \mathrm{~mm}$ in diameter

As compared to the examination performed on 28 May 2015, no significant dynamics was detected. The CT-pattern is more common for a specific process.

The existing data, that is: a positive Mantoux test, absence of BCG vaccination and the expectable effect from nonspecific antibacterial therapy, thoracic CT-scan findings with enlarged bronchopulmonary lymph nodes on the left side combined with hypoventilation of the $\mathrm{S}_{\mathrm{I}}-\mathrm{S}_{\mathrm{IU}}$ left lung segments, made it possible to make a final diagnosis, together with which the child was transferred to Tuberculosis Unit of the Regional Children Infections Clinical Hospital with the following diagnosis: acute hospital left-sided polysegmental pneumonia $\mathrm{S}_{\mathrm{I}}-\mathrm{S}_{\mathrm{III}}$, complicated by bronchial obstructive syndrome. In fact, there is a primary tuberculosis complex, secondary cardiomyopathy, stage I of secondary pulmonary hypertension as well as the syndrome of liquor-dynamic disorders.

The Tuberculosis Unit made a diagnosis in the section: MDRT (multi-drug resistant tuberculosis - 11 August 2015) of the left lung (primary tuberculosis complex (PTC) Destr. - (infiltration phase) $\mathrm{MBT}+, \mathrm{M}+, \mathrm{MG}+(\mathrm{R}+) \mathrm{C}+$ Resist. 1 + (HRZES) Resist. 20 Hist. 0 Cat. 4 Coh. 3 (2015).

The abbreviations means as follows: Destr. - (infiltration phase) - without destruction; MBT - discharges tuberculosis mycobacteriua; $\mathrm{M}+-$ mycobacteria are detected in the swab; MG + - the molecular and genetic analysis was positive; $(\mathrm{R}+)$ mycobacterium resistance; $K+-$ mycobacteria are detected by the cultural methods; Resist. 1 + (HRZES) - the mycobacterium is resistant to primary anti-tuberculosis drugs; Resist. 20- the mycobacterium is susceptible to the second line of antituberculosis drugs; Hist. 0 - histology was not performed; Cat.4 - Category 4; Coh.3 Cohort 3.

As of now, the child continues the treatment in the Tuberculosis Unit. The manifestations of the obstructive syndrome were liquidated.

Conclusions. Having in mind the epidemiologic situation in Ukraine, when examining the child with prolonged bronchial obstructive syndrome, the differential diagnosis is to be made including the specific bronchadenitis and pulmonary involvement. The main pathogenic mechanisms of the bronchial obstructive syndrome development, having regard to the specific tuberculosis process, are as follows: the compression of airways by the enlarged bronchopulmonary lymph nodes.

$$
\text { References }
$$

1. Білогориева О. І., Победъонна Г. П., Рекалова О. М., Доценко Я. І. Особливості стану імунітету у дітей хворих на вперше діа-
1. Bilogortseva O. I., Pobedonna G. P., Rekalova O. M., Dotsenko Ya.I. OsoblivostI stanu ImunItetu u dItey hvorih na vpershe dIag- 
гностований туберкульоз // Укр. пульмонол. журн. - 2015. - № 3. - С. 6-9.

2. Мордык А. В., Пузырёва Л. В., Аксютина Л. П. Современные международные и национальные концепции борьбы с туберкулёзом // Дальневосточный журн. инфекц. патологии. - 2013. - Вып. 22, № 22. - С. 92-97.

3. Нечаева О. Б. Эпидемическая ситуация по туберкулёзу среди детей России // Туберкулёз и болезни лёгких. - 2013. - Т. 90, № 6. - C. 62-63.

4. Охотникова Е.Н., Шарикадзе Е.В. Особенности неотложной терапии синдрома бронхиальной обструкции у детей раннего возраста // Здоровье ребёнка. - 2012. Вып. 39, № 4. - С. 85-92.

5. Соловьёва Н. А. Ильенкова Н. А., Смирнова $C . B$. Бронхообсруктивный синдром у детей грудного возраста // Рос. педиатр. журн. - 2014. - Вып. 17, № 4. - С. 32-38. nostovaniy tuberkuloz // Ukr. pulmonol. zhurn. - 2015. - \#3. - S. 6-9.

2. Mordyik A. V., PuzyirYova L. V., Aksyutina L.P. Sovremennyie mezhdunarodnyie i natsionalnyie kontseptsii borbyi s tuberkulezom // Dalnevostochnyiy zhurn. infekts. patologii. - 2013. - Vyip. 22, \# 22. - S. 92-97.

3. Nechaeva O. B. Epidemicheskaya situatsiya po tuberkulYozu sredi detey Rossii // TuberkulYoz i bolezni lYogkih. - 2013. - T. 90, \# 6. - S. 62-63.

4. Ohotnikova E. N., Sharikadze E. V. Osobennosti neotlozhnoy terapii sindroma bronhialnoy obstruktsii u detey rannego vozrasta // Zdorove rebyonka. - 2012. - Vyip. 39, \# 4. - S. 85-92.

5. Solovyova N. A. Ilenkova N. A., Smirnova S. V. Bronhoobsruktivnyiy sindrom u detey grudnogo vozrasta // Ros. pediatr. zhurn. 2014. - Vyip. 17, \# 4. - S. 32-38.

6. Been J. V., Lugtenberg M.J., Smets E. et al. Preterm birth and childhood wheezing disorders: a systematic review and meta-analysis // PLoS Med. - 2014. - Vol. 11, N 1. - P. 24-28.

7. Dosanjh D., Hinks T., Innes J. et al. Improved diagnostic evaluation of suspected tuberculosis // Ann. Intern. Med. - 2008. - Vol. 148. - P. 325-336.

8. Glaziou P., Falzon D., Floyd K., Raviglione M. Global epidemiology of tuberculosis // Semin. Respir. Crit. Care Med. - 2013. - Vol. 34, N 1. - P. 3-16.

9. Jennifer Lighter, Rigaua Mona. Diagnosing childhood tuberculosis: traditional and innovative modalities // Curr. Probl. Pediatr. Adolesc Health Care. - 2009. - Vol. 39. - P. 61-88.

10. Rekha B., Swaminathan S. Childhood tuberculosis - global epidemiology and the impact of HIV // Pediatr Respir. Rev. - 2007. - Vol. 8, N 2. - P. 99-106.

\section{КЛІНІЧНИЙ ВИПАДОК ТУБЕРКУЛЬОЗУ У ДИТИНИ ГРУДНОГО ВІКУ З БРОНХООБСТРУКТИВНИМ СИНдРОМОМ}

\section{В. А. Клименко, К. О. Яновська, С. В. Пасічник, О. Ю. Марченко (Харків)}

Мета статті - поліпшити верифікацію етіології обструкції у дітей раннього віку шляхом інформування лікарів про рідкісні, складні для діагностики причини обструктивного синдрому, зокрема туберкульоз. Проаналізовано клініко-анамнестичні дані дівчинки 6 міс, наведено дані про лікування й обстеження хворої. В результаті обстеження виявлено, що основним патогенетичним механізмом розвитку бронхообструктивного синдрому було стиснення повітроносних шляхів збільшеними бронхопульмональними лімфатичними вузлами на фоні специфічного туберкульозного процесу в легенях.

Ключові слова: діти грудного віку, пневмонія, туберкульоз, бронхообструктивний синдром.

\section{КЛИНИЧЕСКИЙ СЛУЧАЙ ТУБЕРКУЛЁЗА У РЕБЁНКА ГРУДНОГО ВОЗРАСТА С БРОНХООБСТРУКТИВНЫМ СИНДРОМОМ}

\section{В. А. Клименко, Е. А. Яновская, Е. В. Пасичник, О. Ю. Марченко (Харьков)}

Цель статьи - улучшить верификацию этиологии обструкции у детей раннего возраста путём информирования врачей о редких, сложно диагностируемых причинах обструктивного синдрома, в частности туберкулёз. Проанализированы клинико-анамнестические данные девочки 6 мес, приведены данные о лечении и обследовании больной. В результате обследования выявлено, что основным патогенетическим механизмом развития бронхообструктивного синдрома было сдавление воздухоносных путей увеличенными бронхопульмональными лимфатическими узлами на фоне специфического туберкулёзного процесса в лёгких.

Ключевые слова: дети грудного возраста, туберкулёз, бронхообструктивный синдром. 